\title{
DE KOTOMISI
}

$$
\text { DOOR }
$$

\section{A. J. MORPURGO}

Eenig ter wereld in haar soort is de kotomisi in haar bizarre kleedij, (misschien) potsierlijk voor wie niet ingewijd is in de geheimen van haar toilet. Wie echter den zin kent van haar tooisels, overvloedig tot het overdadige toe, zal daarin niet alleen een graadmeter vinden voor haar welstand - of hetgeen zij daarvoor wil doen doorgaan - doch veelal ook haar gemoedstoestand kunnen onderkennen, benevens een stuk geschiedenis, hetzij van den dag, hetzij eenigszins verouderde, bewaard gebleven in haar costuum.

Daarbij komt dan nog haar smaak en graad van ontwikkeling, zich uitend in de patronen, die zij zich koos.

De kotomisi is - binnen niet al te langen tijd: was, want het zuivere ras sterft uit - niet louter een piramidaal gevaarte van stijf gestreken kleurig katoen, naar willekeur opgebouwd.

Vóór alles behoort er harmonie te zijn in hare kleedij, die samengevat wordt onder den naam „stel”, hetgeen samenstemming veronderstelt.

Tot het stel behooren de wijduitstaande kótó (rok), het pikante korte jákki (jak), de kokette anjisa (hoofddoek), de zwierige tapoe skien pánji (groote schouderdoek), en de geraffineerd nuffige tapoe kótó anjisa, een kleurig doekje, dat achter op den rug vanonder de kotobéré met een punt uitgluurt.

Kan een stel geheel bestaan uit onderdeelen van hetzelfde patroon, afwijkingen zijn geoorloofd, mits de kleuren en lijnen niet het evenwicht verstoren.

Rok en jak - meestal ook de hoofddoek - zijn echter, wanneer de regelen der kleedkunst strikt worden nageleefd, van hetzelfde goed (drukpatroon) vervaardigd.

De rok, het meest in het oog loopende onderdeel van het stel, is van buitengewonen omvang in de breedte. De lengte is van dien aard, dat zij reikt van de schouders tot de voeten. Wat er aan

West-Indische Gids XVI 
lengte teveel is tusschen oksels en middenlijf wordt neergeslagen over den buikband, zóó dat er een zakvormig aanhangsel ontstaat, loopend om het lijf.

Bij deftige kleeding wordt dit overhangend deel, de koto-béré (letterlijk: rokbuik), niet gebruikt, doch bij werkkleeding dient zij om er allerhande in te bergen, hetgeen uitstekend gaat. Van boven is n.l. de kotobéré gesloten door den buikband en de vastgehechte boord der kótó, en slechts aan de voorkant is zij open door een smal spleetje.

Om de kótó in gebruik den gewenschten omvang te geven, wordt gebruik gemaakt van een langrond kussen, famiri (familie) genoemd, dat hoog op den rug wordt bevestigd en is te vergelijken met de crinoline, door de mode aan een vorige generatie in Europa voorgeschreven.

Volledig gekleed is de kotomisi niet zonder kralen, in lange snoeren afhangend, soms tot de knieën, en polsbanden, eveneens van kralen. Deze kunnen zijn van dezelfde soort, doch ook andere zijn toegelaten.

Met haar tijd meegaande weet de kotomisi ook halskettingen en armbanden van goud en zilver te waardeeren. Gehecht als zij is aan het eigene, kan men haar niet zelden zonder bezwaar kralen en halskettingen in zware strengen zien vereenigen om den hals en. metalen. armhanden. met. kxalen. om. de polsen.

Evenals de stellen in hun geheel en de hoofddoeken afzonderlijk hebben ook de kralen zinrijke namen, die veelal niet anders zijn dan aphoristische toespelingen op bepaalde gebeurtenissen, ontleend aan de politiek of de chronique scandaleuse.

Want waar zij ook onverschillig voor zal zijn, voor deze twee rijke bronnen tot conversatie is de Surinaamsche negerin het allerminst!

Hoofddoek, kralen, stof voor het stel, worden natuurlijk ingevoerd zonder naam. Deze wordt er door plaatselijke verkoop(st)ers - enkele alom bekende adressen - aan gegeven op verzoek van vreemden, die zelfs geen klant behoeven te zijn, om van deze gelegenheid te profiteeren hun veeten wereldkundig te maken en hun tegenstanders te treffen.

Dezen laten zich natuurlijk niet onbetuigd en beantwoorden de wederpartij met een nieuwen schimpscheut, die op hun verzoek wederom aan een nieuw stel of een nieuwen doek wordt gegeven.

Deze strijd wordt wel eens lang voortgezet, zoodat er een serie ontstaat, welke grif afzet vindt. 
Het best leenen zich - met het oog op de kosten - de hoofddoeken voor deze namengeverij, waaraan men geest meermalen niet kan ontzeggen.

De „verschijning” van een nieuwen hoofddoek is met verbazingwekkende snelheid bekend onder de liefhebsters, die haast als verzamelaarster kunnen worden aangemerkt, zooals men ook verzamelaarsters van postzegels kent. Met dezelfde passie streven zij ernaar iedere nieuwigheid op dit gebied te bemachtigen, daarbij zorg dragend den naam te leeren kennen met de geschiedenis, die den oorsprong daarvan aangeeft. Vooral onder de ouderen vindt men verzamelaarsters, die hun bezit aan hoofddoeken bij honderden tellen.

De verschijning wordt aangekondigd met: anjisa ópó. Dat "opo" is reeds teekenend. Het kan zoowel opstaan, opgaan - van hemellichamen - als open bloeien beteekenen en sluit hoodzakelijk in, dat er aan den nieuwen hoofddoek iets bizonders is, in dit geval een naam. Want zou de doek zonder naam gelanceerd worden, dan denkt men er niet aan te spreken van „opo".

Om met een tweetal namen te volstaan, slechts de volgende.

Een bekende hoofddoek heet: „Joe bin dé framingo, joe tron geer das", d.i. Je was flamingo - een groote mooie vogel - en je bent geeldas geworden - een klein, onaanzienlijk vogeltje.

Dit slaat natuurlijk op een gebeurtenis, betrekking hebbend op den een of ander in onze samenleving.

Van een bekend stel is de naam: „Wanwan boen lobi dé, ma din dé na s'ma anoe", d.i. er zijn nog heel enkele trouwe minnaars, maar die behooren anderen (reeds) toe.

Opmerkelijk, dat de teerste en intiemste zaken als bij voorkeur hiervoor dienen.

Is de hoofddoek reeds de aandacht waard om de naam, waarmede hij gelanceerd wordt, ook de wijze van strikken verdient opgemerkt te worden.

Dit strikken geschiedt voor bepaald gebruik steeds volgens vaste regels.

Daarenboven onderscheidt men - in de klasse der straatdeernen - bizondere wijzen van strikken met een geijkte, min of meer sterk gekruide beteekenis.

De hoofddoek, tot hoofdbedekking gestrikt, heet tai-hédé. (Tai is strikken, binden; hédé is hoofd).

De taihédé wordt onderscheiden in strikkihédé en in lontoehédé. De strikkihédé (strikki is strikken) dient voor dagelijksch gebruik. De lontoe-hédé (lontoe is rond) dient voor bizondere gele- 
genheden, die in hoofdzaak zijn te onderscheiden in feestelijke en rouwgelegenheden.

In aansluiting daarop zijn er dan ook twee soorten lontoehede, t.w. de lô-hédé en de pródó-hédé. (Lô is rouw en pródó is pronken).

Het onderscheid en de namen houden verband met de wijze van strikken.

Om de taihédé te strikken, wordt de doek, die in den regel vierkant is, langs een der diagonalen dubbel gevouwen, zoodat er een driehoek ontstaat. Deze wordt om het voorhoofd gelegd met de basis langs het voorhoofd, de top- en basishoeken naar achteren leidend.

Om nu een strikki-hédé te vormen, worden de basis-einden achter aan het hoofd gestrikt en wel zoo, dat de top eronder wordt vastgelegd. Met behulp van spelden wordt dan de vorm verder opgemaakt.

Het verschil met de lontoe-hédé bestaat hierin, dat voor de lontoe-hédé de basisuiteinden, die achter aan het hoofd kruiselings over elkander worden gelegd, niet daar bij elkander gestrikt worden, doch langs de slapen naar het voorhoofd worden teruggeleid en op het voorhoofd worden vastgemaakt. De vorm is dan inderdaad rond.

Bij lontoe-hédé's, die als lô-hédé moeten dienen, ontbreken alle versieringen. Het model blijft vlak. Bij de prodohédé daarentegen komen versieringen voor. Deze kunnen gevonden worden in uitstulping of plooiing van de randen, of in lint, dons en andere hulpmiddelen, die erop gehecht worden.

De prodohédé verkrijgt wel eens zulk een omvang, dat men oneerbiedig spreekt van bátji (bak).

Een apart aanhangsel komt bij rouwhoofddoeken voor. Men onderscheidt hierbij de tónpi (onvertaalbaar) en de tjettjari (drager).

De tonpi bestaat uit een doek, die over den rouwhoofddoek wordt gelegd en onder den kin vastgeknoopt. Hiermede wordt de diepste rouw te kennen gegeven.

De tjětjari bestaat uit een vierkante lap, op den rouwhoofddoek gespeld, met de punten afhangend tot ongeveer ter hoogte van de slapen. Ook deze dient om de "diepte" der rouw te accentueeren, doch staat daarin achter bij de tónpi.

In tegenstelling met de tónpi wordt de tjětjari niet gedragen bij de begrafenis. Eerst acht dagen na de begrafenis, wanneer de ei- 
genlijke rouwdracht wordt aangenomen, treedt de tjětjari op. Verder wordt zij den geheelen rouwtijd gedragen.

Weduwen, die haar echtgenoot, of moeders, die haar volwassen kinderen grafwaarts dragen, gebruiken in den begrafenisstoet en gedurende de eerste acht dagen de tónpi. Daarna kunnen zij volstaan met de tjětjari.

Tjětjari en tónpi moeten in dezelfde kleur als de hoofddoek gekozen worden. Opmerking verdient hierbij, dat de rouwkleur bij begrafenissen en gedurende de eerste acht dagen daarna wit is. Gedurende den rouwtijd zwart of donkerblauw, naar gelang de diepte der rouw.

De tjĕtjari heb ik wel eens prakseeri (overpeinzing, beslommering) hooren noemen.

Deze tjětjari moet niet verward worden met den ineengedraaiden doek, die als kussentje op het hoofd dient bij het torsen van zware lasten, en ook tjĕtjari heet.

(De negerinnen dragen alles op het hoofd. Van enorme vrachten landbouwproducten, die een man te zwaar zouden zijn, tot een enkel fleschje of kopje. Zonder het gedragene met de hand of op andere wijze te steunen, staat alles even veilig op het hoofd, als stond het op een tafel. Ook al zou de draagster onderweg heftig gesticuleerend een ruzietje uitkijven op de gebruikelijke wijze. Variété-artisten zouden in verlegenheid gebracht kunnen worden door een uitdaging haar na te doen).

Onder de vrouwen uit de heffe des volks zijn eenige wijzen van strikken met pikante beteekenis bekend. Eenige der voornaamste volgen hier.

Door de beschreven wijze van strikken bestaat hetgeen ik aanduidde als topgedeelte, en dat naar achteren wordt geleid, uit twee driehoekige kleppen, met de punt naar achteren.

Hebben nu twee dezer dames ruzie, en gaat een harer zich te buiten aan schimpen en schelden - wat kan duren van 's morgens vroeg tot 's avonds laat en zelfs dagen achtereen kan worden voortgezet - dan kan de ander, wanneer zij er niet op wenscht in te gaan, haar minachting door middel van haar taihédé tot uitdrukking brengen.

Daartoe zet zij een der kleppen steil overeind, in plaats van deze vast te maken onder de zijstukken. Dit beteekent dan: „Aspassia é takki nanga tanta", d.i. Aspassia (vrouwennaam, ge- 
fingeerd) spreekt tot tante. (Tanta is de aanspreektitel voor oudere vrouwen).

Aangezien nu de draagster geen Aspassia heet, de naam niet voorkomt, is de beteekenis dus: „Scheld maar raak. $I k$ keur je geen antwoord waard".

Helpt dit niet, dan weet de kijvende er wel raad op: nu gaan beide kleppen omhoog. zoodat het achterhoofd en de kruin zichtbaar worden.

De juiste beteekenis hiervan (Lek me de mars) is van zoo duidelijke beteekenis, dat vertaling overbodig is.

Een andere wijze van strikken bestaat hierin, dat de beide bedoelde kleppen als het ware geregen worden door de samengestrikte uiteinden, zoodanig dat zij daaruit recht naar achteren uitschieten. De hieraan gehechte beteekenis luidt: Sârgi masra, (Wijlen meneer, of meneer zaliger). Deze wijze van strikken wordt gebezigd door verdachte vrouwen of maîtresses om den dood van een „relatie" kenbaar te maken.

Van eenigszins beter gehalte is het vlak binden van den doek met slechts een stompje, uitschietend ter linkerzijde. Hiermede wordt tegen vijandinnen een bekende zegswijze gelucht: „A no mi lafoe konkoni méki a no habi téré", d.i. Het konijn mist zijn staart niet, omdat ik het uitlach, m.a.w. mijn schuld is het niet als jij in een of ander opzicht bespottelijk mocht zijn.

Bekend is ook de fit'-kaka (féti, afgekort tot fit' is vechten en $k a k a$, afkorting van kakaforoe, is haan; dus kemphaan).

Van deze wijze van strikken bedienen de dames zich als alle minder drastische middelen zijn uitgeput en de eer eischt, dat er gevochten wordt. Bij dergelijke vechtpartijen delft veelal het onderspit de partij die het eerst getroffen wordt in de gevoelige plek..... de haren. Het model fit' kaka nu, is er op berekend alle haren zorgvuldig weg te binden en in veiligheid te stellen, zoodat de tegenpartij deze niet te pakken kan krijgen.

Uit dit weinige kan men reeds zien, hoeveel er door een kleine wijziging in een onderdeel van het toilet wordt uitgedrukt.

Men kan hieruit zien hoe welbespraakt de kotomisi, de Surinaamsche negerin eigenlijk is en tevens hoe strijdvaardig en hoe weinig kieskeurig zij kan zijn.

Men meene echter niet, dat hiermede de mogelijkheden zijn uitgeput. Met dit weinige moge echter volstaan worden om even 
nog met een enkel woord de alanja-tiki, het oranjestokje, te bespreken.

Dit stokje, gesneden van een jonge tak der zure oranje, heeft een tweeledige bestemming. In de eerste plaats dient het ter zuivering van den adem (door de etherische olie in de bast) en ter poetsing der tanden (met het kwastvormig afgekauwd uiteinde).

Het gebruik van het stokje behoeft echter niet angstvallig verborgen te blijven tot de toilet-kamer, doch mag ook in het openbaar zoo noodig, plaats vinden. En noodig vindt de negerin dit altijd, want weinig dingen schuwt zij zoozeer als aanmerkingen op de helderheid van haar gebit.

$\mathrm{Zij}$ zou echter niet zijn die zij is, als het stokje ook niet gebezigd werd om gedachten tot uiting te brengen.

Een enkel voorbeeld slechts.

Het stokje, voorzien van de schutbladen, bij ruzies met gratie gehanteerd en geplant in den rechter mondhoek, heeft zijn scherpe, afdoende beteekenis. Gesproken wordt er niet bij, ter verhooging van het effect. Hoogstens klinkt er een uitdagend p' $h$ 'eoe bij, tartend met gedempte stem gegild. Want het stokje alleen zegt reeds „Skijt wat”, hetgeen zooveel beteekent als: Ik heb maling aan je. Aan jou en je praatjes.

Men ziet het: de kotomisi is niet op haar mondje gevallen.

Vindingrijkheid zal men haar intusschen niet ontzeggen.

Ze heeft echter meer.

Ze heeft ontegenzeggelijk gratie, als ze met de armen stijf langs de omvangrijke koto en het hoofd trots in den nek aantrippelt, met korte pasjes, draaiende beweginkjes, waarin de plankstijve koto ritselend deelt: srr, srr, zooals zij het hoort.

Ze heeft gratie en is aantrekkelijk van eerbiedige aanhankelijkheid als ze tegenover den gran-bakrá (voorname) haar kási maakt, de korte knik met de knieën, driemalen herhaald - de hoogste reverentie - daarbij de handen aldoor eerbiedig samengebracht. ter hoogte van het middenlijf en driemaal het bovenlijf draaiend van links naar rechts, van rechts naar links, terwijl de koto zwaar ruischend in stijve plooien meedraait, in kleurenbeweeg van het bonte patroon.

Deze kotomisi echter, de echte, van den ouden stempel, is zeldzaam. Haar ras sterft uit.

Het opgroeiend geslacht wendt zich af van haar dracht, waarop zij zoo trotsch was, kleedt zich als de Europeesche dame.

Wel bleef het grootendeels de tai-hédé trouw, maar ..... van de pompadour-patronen en crêpe de Chine-coupons, waaruit zij 
zich een Europeesch toilet - volgens de allerlaatste mode! liet naaien, strikt zij zich - o, gruwel! - een strikki-hédé, die voor de echte kotomisi slechts denkbaar is in ordinair bedrukt katoen, voor dagelijksch gebruik, doch nooit bij deftiger dracht bij beter stof de lontoe-hédé zal vervangen, evenmin als de Europeesche bij naar avondtoilet een oilskin regenhoedje of tennisschoenen zal dragen!

Zoo is nu echter de tijdgeest, die in het jonge geslacht is gevaren, en dat verleidt om de traditie met voeten te treden.

Met de statige, zinrijk gekleede kotomisi verliest Paramaribo een zijner schilderachtige aspecten vol bonte verscheidenheid, waardoor de vreemdeling steeds getrokken werd.

Paramaribo. 